\title{
Voltammetric Assay of Metformin Hydrochloride Using Pyrogallol Modified Carbon Paste Electrode
}

\author{
Ali K. Attia,* Waheed M. Salem and Mona A. Mohamed \\ National Organization for Drug Control and Research, P.O. Box 29, Cairo, Egypt \\ * Corresponding author: E-mail: alikamal1978@ hotmail.com \\ Tel.: 002 0235851278; Fax: 0020235855582
}

Received: 30-08-2014

\begin{abstract}
The electrooxidative behavior and determination of metformin hydrochloride, anti-hyperglycemic drug, on a pyrogallol modified carbon paste electrode were investigated using cyclic voltammetry and differential pulse voltammetry. Metformin hydrochloride shows an irreversible oxidation behavior over a wide interval of $\mathrm{pH}$ (Britton-Robinson buffers, $\mathrm{pH}$ $2-9)$. The peak current varied linearly in the range comprised between $8.0 \times 10^{-7}$ and $6.0 \times 10^{-6} \mathrm{~mol} / \mathrm{L}$ with detection limit of $6.63 \times 10^{-8} \mathrm{~mol} / \mathrm{L}$ and limit of quantification of $2.21 \times 10^{-7} \mathrm{~mol} / \mathrm{L}$. The method was proposed for the determination of metformin hydrochloride in dosage forms and urine.
\end{abstract}

Keywords: Voltammetry, Carbon Paste Electrode, Pyrogallol, Metformin, Determination, Urine.

\section{Introduction}

Metformin hydrochloride (MET) (Fig. 1) is an orally administered antidiabetic that lowers glucose blood level by reducing hepatic glucose production and gluconeogenesis and by enhancing peripheral insulin sensitivity. ${ }^{1-3}$ Published methods for the determination of MET are based on different techniques like capillary electrophoresis, ${ }^{4,5}$ NMR spectrometry, ${ }^{6}$ potentiometry, ${ }^{7-9}$ spectrofluorimetry and spectrophotometry, ${ }^{9-20}$ conductometry, ${ }^{21,22}$ voltammetry, ${ }^{23-29}$ IR spectrometry ${ }^{30}$ and chromatography. ${ }^{31-39}$ a)<smiles>Oc1cccc(O)c1O</smiles>

b)<smiles>CN(C)C(=N)NC(=N)N</smiles>
. $\mathrm{HCl}$

Figure 1: Chemical structures of PY (a) and MET (b).

Although many of the reported methods are accurate and sensitive, they require the use of sophisticated equipment and expensive reagents. Some are cumbersome, requiring prolonged sample pretreatment, strict control of p$\mathrm{H}$ and long reaction times. An easy, fast, cost-effective voltammetric method for the determination of MET in bulk drug and tablets is thus needed being applicable to routine quality control of the drug in resource-limited countries. This was the primary motivation for this research, in which MET was determined voltammetrically.

Carbon paste electrode (CPE), which was made up of carbon particles and organic liquid, has been widely applied in the electroanalytical community due to its low cost, ease of fabrication, high sensitivity for detection and renewable surface. Lately, to improve the sensitivity, selectivity, detection limit and other features of CPE, modified carbon paste electrodes have been used. ${ }^{40-42}$

Pyrogallol (PY) (Fig. 1) is an electroactive compound. ${ }^{43,44}$ Therefore; it can be used as modifier to prepare pyrogallol modified carbon paste electrode (PYCPE) for the electrochemical determination of MET in bulk, tablets and urine.

\section{Experimental}

\section{1. Materials and Reagents}

Graphite powder and paraffin oil were purchased from Sigma-Aldrich. Metformin hydrochloride powder was obtained from El Nasr Pharmaceutical Chemicals Company, Egypt. Cidophage tablets (500 mg (MET)/tab) were obtained from Chemical Industries Development Company, Egypt. Pyrogallol was purchased from Alpha 
Chemika, Mumbai, India. All other chemicals were of analytical grade and used without further purification. Britton-Robinson (BR) buffer solution of $\mathrm{pH}$ from 2.0 to 9.0 was used as the supporting electrolyte. Buffer solutions were adjusted by adding the necessary amount of $0.2 \mathrm{~mol} / \mathrm{L} \mathrm{NaOH}$.

\section{2. Instrumentation}

All voltammetric measurements were performed using a personal computer controlled AEW2 electrochemistry work station and data were analyzed with ECProg3 electrochemistry software, manufactured by SYCOPEL SCIENTIFIC LIMITED (Tyne \& Wear, UK). The one compartment cell with the three electrodes was connected to the electrochemical workstation through a C-3 stand from BAS (USA). PYCPE was used as working electrode, a platinum wire (BAS model MW-1032) was employed as counter electrode. All the cell potentials were measured with respect to $\mathrm{Ag} / \mathrm{AgCl} / 3 \mathrm{~mol} / \mathrm{L} \mathrm{NaCl}$ (BAS model MF2063) reference electrode.

\section{3. Preparation of the Working Electrode}

PYCPE was prepared initially by mixing appropriate amounts of graphite powder (particle size: $<20 \mu \mathrm{m}$ ), PY and paraffin oil (flash point: $215^{\circ} \mathrm{C}$ ). Then the resulted composite was dispersed in methanol to obtain better homogeneity. Best results were obtained at 66:30:4 (w/w \%) ratio of graphite powder, paraffin oil and PY, respectively. The prepared modified composite material was then dried at room temperature. The obtained paste was packed into the hole of the electrode body and smoothed on a filter paper until it had a shiny appearance.

The same procedure in the absence of PY was used for constructing CPE 70:30 (w/w \%) ratio of graphite and paraffin oil.

\section{4. Determination of MET in Bulk}

The three electrodes were immersed in the voltammetric cell which contains $5 \mathrm{~mL}$ of BR buffer solution ( $\mathrm{p}$ $H$ 2.0). An appropriate volume of MET solution was added to the electrolytic cell in the concentration range of $8.0 \times 10^{-7}-6.0 \times 10^{-6} \mathrm{~mol} / \mathrm{L}$. The solution was stirred for $50 \mathrm{sec}$ at open circuit conditions. The stirring was stopped for a period of $5 \mathrm{sec}$ (equilibration time) and then, the potential was scanned from 0.8 to $1.1 \mathrm{~V}$ using differential pulse voltammetry (DPV) at a scan rate of $20 \mathrm{mV} / \mathrm{s}$. Voltammetric analyses were carried out and the voltammograms were recorded.

\section{5. Determination of MET in Tablets}

Five tablets of cidophage were weighed and the average mass per tablet was determined, then these tablets were powdered. A portion of the finely powder needed to obtain $1.0 \times 10^{-3} \mathrm{~mol} / \mathrm{L}$ MET solution was accurately weighed and transferred into $100 \mathrm{~mL}$ volumetric flask which contains $70 \mathrm{~mL}$ of distilled water. The flask was sonicated for about 20 min and made up the volume with the same solvent. The solution was then filtered to separate out the insoluble excipients, rejecting the first portion of the filtrate. Aliquots of the drug solution were introduced into the electrolytic cell and the general procedure was carried out.

\section{6. Determination of MET in Urine}

For the determination of MET in spiked urine samples in the concentration range of $1.6 \times 10^{-6}-5.6 \times$ $10^{-6} \mathrm{~mol} / \mathrm{L}$, urine $(1.0 \mathrm{ml})$ was mixed with $9.0 \mathrm{ml}$ of BR buffer of $\mathrm{pH} 2.0$, without any pretreatment, and transferred to the voltammetric cell. The differential pulse voltammetric procedure was carried out as for the pure drug.

\section{Results and Discussion}

\section{1. Electrochemical Behavior of MET}

The electrochemical behavior of PYCPE was studied by using cyclic voltammetry (CV) in BR buffer ( $\mathrm{pH} 2.0)$, the cyclic voltammogram exhibits an anodic peak at forward scan and a cathodic peak at the reverse scan related to the oxidation and reduction of PY (Fig. 2).

Fig. 3 shows the cyclic voltammograms of $1.0 \times$ $10^{-3} \mathrm{~mol} / \mathrm{L}$ MET solution in BR buffer of $\mathrm{pH} 2.0$ at CPE and PYCPE. Each voltammogram showed an irreversible anodic peak due to the electrochemical oxidation of an imino group in guanidine group to $N$-hydroxy imino group then fast hydrolysis of $N$-hydroxy imino group to a carbonyl imino group (Fig. 4). The sa-

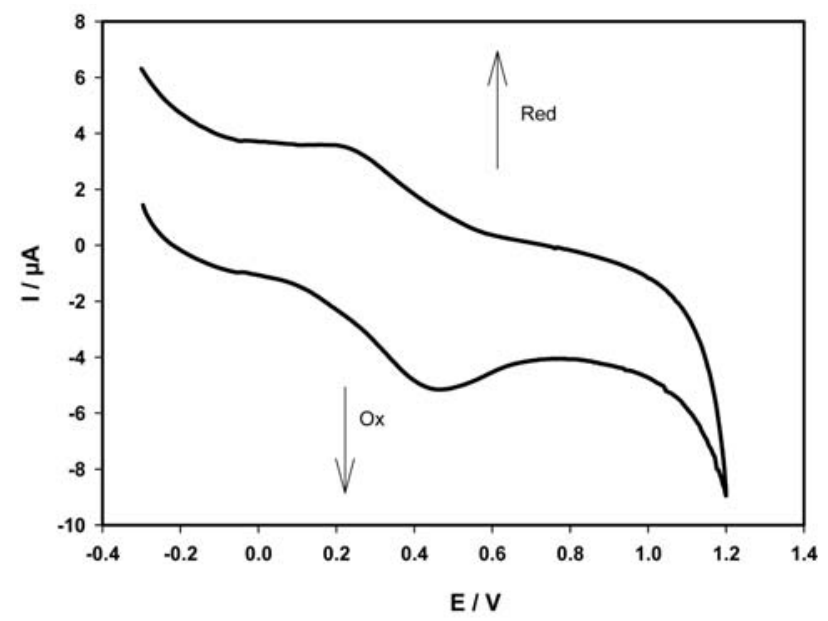

Figure 2: Cyclic voltammogram of PYCPE in BR buffer ( $\mathrm{pH}$ 2.0). Scan rate of $100 \mathrm{mV} / \mathrm{s}$. 


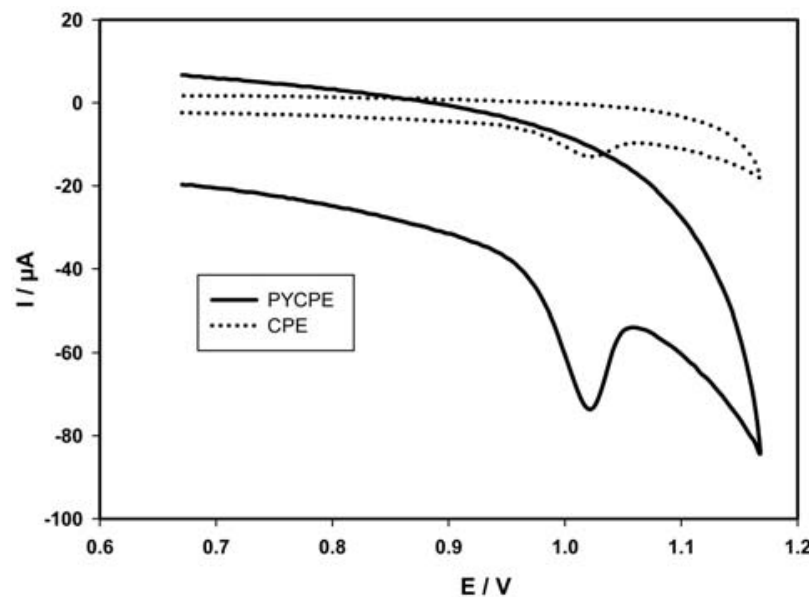

Figure 3: Cyclic voltammograms of $1.0 \times 10^{-3} \mathrm{~mol} / \mathrm{L}$ MET solution in BR buffer (pH 2.0) at CPE and PYCPE. Scan rate of $100 \mathrm{mV} / \mathrm{s}$.<smiles>CN(C)C(=N)NC(=N)NC(=N)N(C)C(=N)NC(N)=O</smiles>

Figure 4: Suggested oxidation mechanism of MET.

me behavior has been reported for electrooxidation of MET. ${ }^{23-26}$ From figure (3), it was noted that the value of the anodic peak current in case of PYCPE $(73.92 \mu \mathrm{A})$ is much higher than that in case of CPE $(13.12 \mu \mathrm{A})$ indicating the enhancement effect of PY as an effective mediator resulted in a considerable improvement in the oxidation peak current of MET and thus the modified electrode showed a catalytic behavior in electrooxidation of MET.

\section{2. Effect of $\mathrm{pH}$}

It is important to investigate the effect of $\mathrm{pH}$ on voltammetric behavior of MET at PYCPE over a wide interval of $\mathrm{pH}$ (Britton-Robinson buffers, $\mathrm{pH}$ 2-9) (Fig. $5 \mathrm{~A})$. It is concluded from the figure that the maximum peak current value was obtained at $\mathrm{pH} 2.0$ and after this value the anodic current decreased as the $\mathrm{pH}$ value increased (Fig. 5B) suggesting the decrease in the electrocatalytic activity of PYCPE. Therefore, $\mathrm{pH} 2.0$ was chosen as the optimum $\mathrm{pH}$ value for determination of
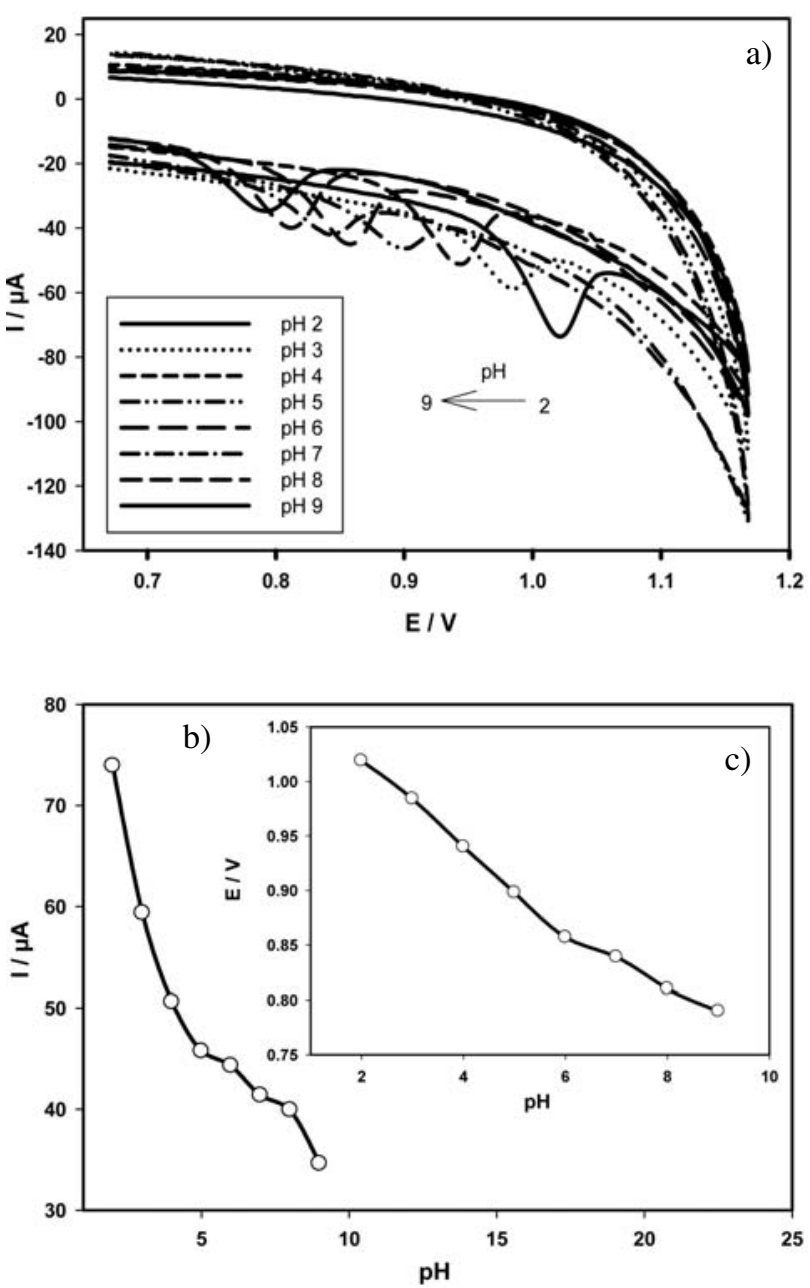

Figure 5: Cyclic voltammograms of $1.0 \times 10^{-3} \mathrm{~mol} / \mathrm{L}$ MET at PYCPE in BR buffers (2.0-9.0) (A). Relation between anodic peak current of $1.0 \times 10^{-3} \mathrm{~mol} / \mathrm{L}$ MET and $\mathrm{pH}(\mathrm{B})$ and inset: Relation between anodic peak potentials (C) of $1.0 \times 10^{-3} \mathrm{~mol} / \mathrm{L}$ MET and $\mathrm{pH}$.

MET. Fig. 5C showed that the $\mathrm{pH}$ of the solution had a significant influence on the anodic peak potentials of the oxidation of MET, i.e. the anodic peak potentials shifted negatively (decreased) with the increase of the solution $\mathrm{pH}$ indicating that the electrocatalytic oxidation of MET at PYCPE was $\mathrm{pH}$ dependent reaction and that protons had taken part in their electrode reaction processes.

\section{3. Effect of PY Content}

Fig. 6 showed the cyclic voltammograms of MET in BR buffer of $\mathrm{pH} 2.0$ by using PYCPE containing different amounts of PY. From the figure it was noted that the anodic peak current increased as the content of PY in the carbon paste increases up to $4 \%$ then the anodic current decreased, thus the best results were obtained at 66:30:4 $(\mathrm{w} / \mathrm{w} \%)$ ratio of graphite powder, paraffin oil and PY, respectively. 


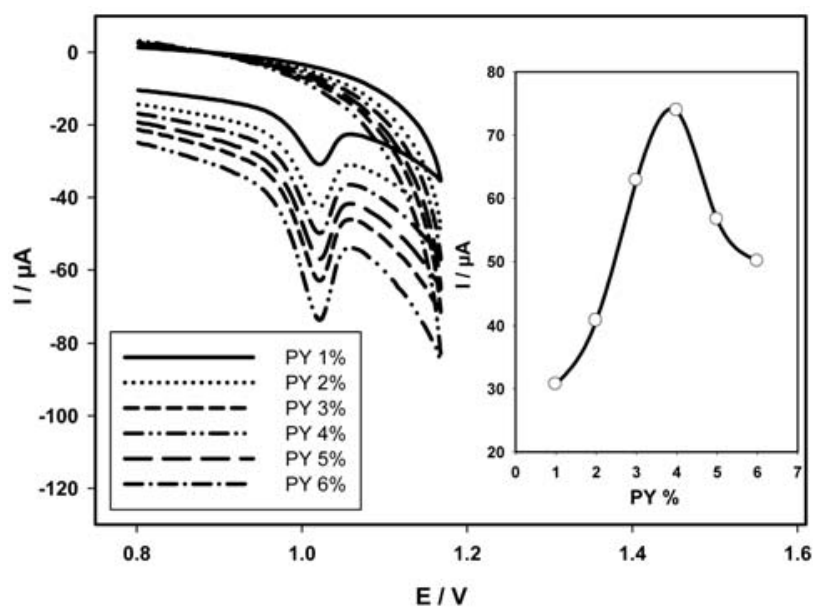

Figure 6: Cyclic voltammograms of $1.0 \times 10^{-3} \mathrm{~mol} / \mathrm{L}$ MET solution in BR buffer of pH 2.0 at PYCPE of different contents of PY. Scan rate of $100 \mathrm{mV} / \mathrm{s}$. The inset: plot of the anodic peak current values versus PY content.

\section{4. Effect of Scan Rate}

The effect of different scan rates (ranging from 10 to $250 \mathrm{mV} / \mathrm{s}$ ) on the oxidation peak current response (I) of MET $\left(1.0 \times 10^{-3} \mathrm{~mol} / \mathrm{L}\right)$ at PYCPE in BR buffer $(\mathrm{pH} 2.0)$ was studied and a plot of I versus the square root of the scan rate $\left(v^{1 / 2}\right)$ gave a straight line relationship, which expressed by the linear regression equation of $\mathrm{I}(\mu \mathrm{A})=8.09$ $\mathrm{v}^{1 / 2}(\mathrm{mV} / \mathrm{s})-8.49$, with a correlation coefficient of 0.999 .

(Fig. 7). This revealed that the linearity of the relationship was realized up to a scan rate of $150 \mathrm{mV} / \mathrm{s}$ followed by a deviation from linearity with further increase of the scan rate. This indicated that the charge transfer was under diffusion control partially and that the adsorption of aggregates at the electrode surface was also possible. In Fig. 8 a linear relationship was observed between $\log \mathrm{I}$ and $\log \mathrm{v}$

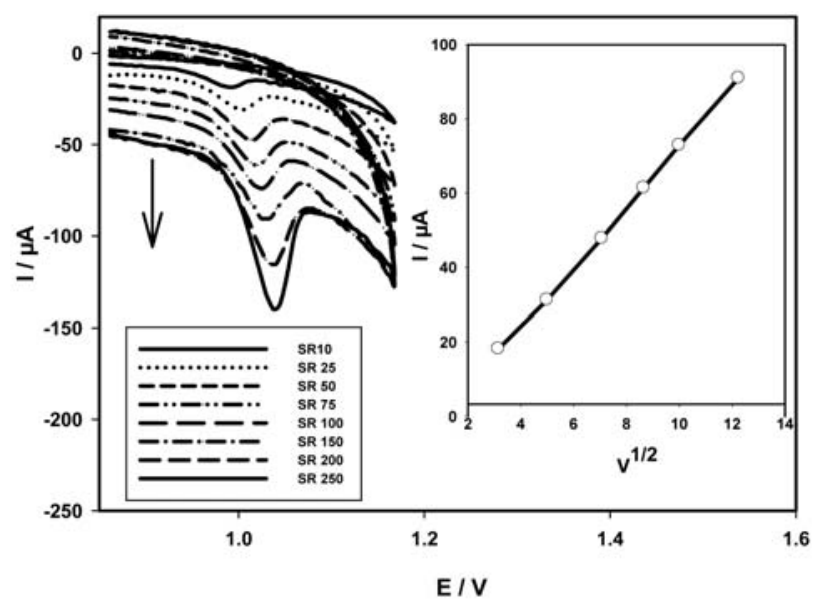

Figure 7: Cyclic voltammograms of $1.0 \times 10^{-3} \mathrm{~mol} / \mathrm{L}$ MET at PYCPE in BR buffer of pH 2.0 at: 10, 25, 50, 75, 100, 150, 200 and $250 \mathrm{mV} / \mathrm{s}$. The inset: plot of the anodic peak current values versus square root of scan rate $\left(v^{1 / 2}\right)$.

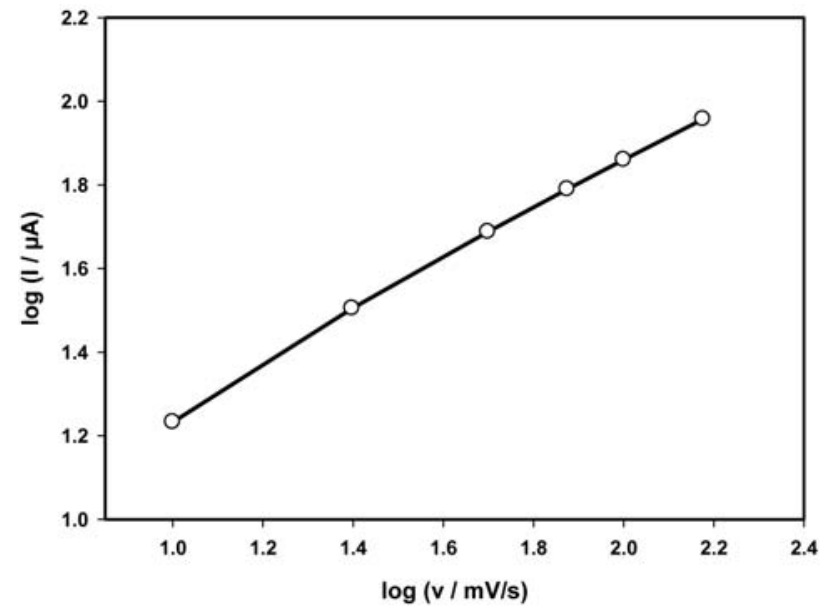

Figure 8: Anodic peak current response of $1.0 \times 10^{-3} \mathrm{~mol} / \mathrm{L}$ MET solution at PYCPE as a function of scan rate (v) in BR Buffer of $p$ H 2.0.

over the scan range from 10 to $250 \mathrm{mV} / \mathrm{s}$ and corresponded to the following equation: $\log \mathrm{I}=0.632+0.615$ $\log v$, with a correlation coefficient of 0.999 , The slope of 0.615 suggesting that the oxidation reaction of the analyte species took place at the electrode surface under the diffusion of the molecules from solution to the electrode surface with some adsorption character. ${ }^{45}$

\section{5. Effect of Accumulation Time}

The effect of accumulation time $\left(\mathrm{T}_{\mathrm{acc}}\right)$ on the anodic peak current of $1.0 \times 10^{-3} \mathrm{~mol} / \mathrm{L}$ MET solution was studied at PYCPE in BR buffer of $\mathrm{pH} 2.0$ at open circuit condition. The results were shown in Fig. 9. From the figure we note that the anodic peak current increased with accumulation time up to $50 \mathrm{sec}$, after this value, the current value gradually decreased as the time increased then

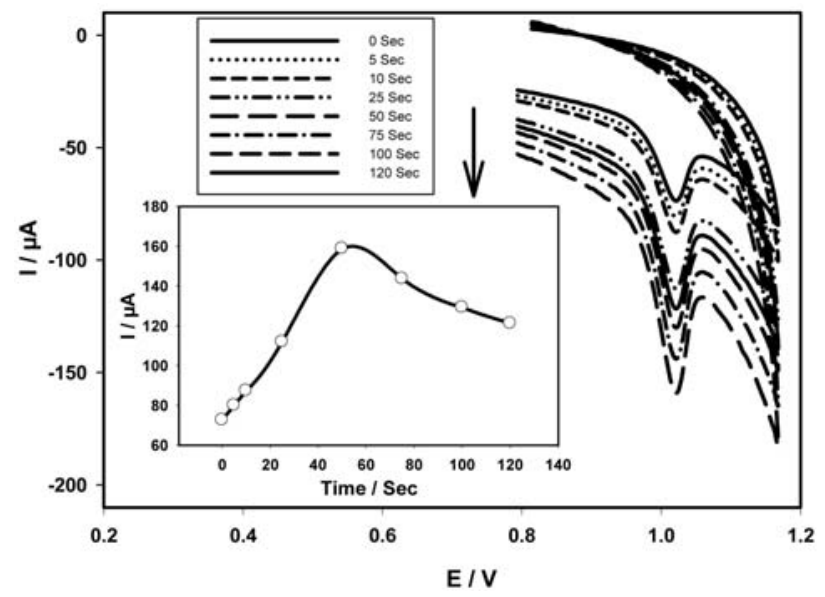

Figure 9: Anodic peak current of $1.0 \times 10^{-3} \mathrm{~mol} / \mathrm{L}$ MET solution at PYCPE as a function of accumulation time in BR Buffer of $\mathrm{pH}$ 2.0. The inset: plot of the anodic peak current values versus accumulation time. 
the anodic current reached a steady state indicating that the surface of the working electrode was saturated with drug. Hence, $50 \mathrm{sec}$ was chosen as the optimum accumulation time.

\section{6. Determination of MET in Bulk}

On the basis of the electrochemical oxidation of MET at PYCPE, analytical method was developed using DPV for the determination of MET in the bulk. A linear response was obtained in the range from $8.0 \times 10^{-7}$ to 6.0 $\times 10^{-6} \mathrm{~mol} / \mathrm{L}$. The calibration plot (Fig. 10) was described by the following equation: $\mathrm{I}(\mu \mathrm{A})=3.608 \mathrm{C}(\mu \mathrm{M})+$ $0.361, \mathrm{r}^{2}$ (Correlation coefficient $)=0.999$. The limits of detection (LOD) and quantification (LOQ) were calculated by using the following equations: $\mathrm{LOD}=3 \mathrm{SD} / \mathrm{m}$ and $\mathrm{LOQ}=10 \mathrm{SD} / \mathrm{m}$, where "SD" is the standard deviation of the intercept of the calibration curve and " $\mathrm{m}$ " is the slope of the calibration curve. ${ }^{46}$ The LOD and LOQ were $6.63 \times$ $10^{-8} \mathrm{~mol} / \mathrm{L}$ and $2.21 \times 10^{-7} \mathrm{~mol} / \mathrm{L}$, respectively.

Accuracy and precision of the proposed method were determined by replicate analyses of four different concentrations of MET $\left(8.0 \times 10^{-7}, 2.4 \times 10^{-6}, 3.2 \times 10^{-6}\right.$ and $\left.4.8 \times 10^{-6} \mathrm{~mol} / \mathrm{L}\right)$. The recovery was found in the range from $99.38 \%$ to $101.15 \%$ and the relative standard deviation (RSD) was in the range from $1.38 \%$ to $2.13 \%$.

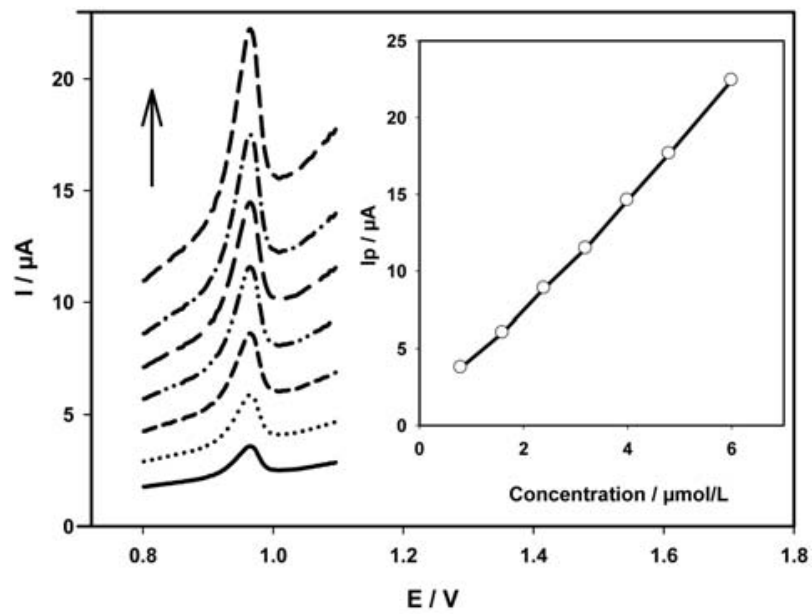

Figure 10: The effect of changing the concentration of MET, using differential pulse mode at PYCPE in BR buffer $(\mathrm{pH} 2.0), \mathrm{T}_{\text {acc }}=50$ sec and scan rate of $20 \mathrm{mV} / \mathrm{s}$. The inset: the relation between MET concentration and the current responses.
The repeatability of the proposed voltammetric procedure was assessed on the basis of seven measurements of $2.4 \times 10^{-6} \mathrm{~mol} / \mathrm{L}$ MET solution, the RSD was found to be $1.93 \%$ indicating excellent reproducibility of the used method.

Robustness was carried out using $3.2 \times 10^{-6} \mathrm{~mol} / \mathrm{L}$ MET by varying three parameters (deliberate change) from the optimum conditions of the method like $\mathrm{pH}(2.0 \pm$ $0.2)$, accumulation time ( $50 \pm 3 \mathrm{sec})$ and PY content (4.0 $\pm 0.1 \%, \mathrm{w} / \mathrm{w})$. The RSD values were $0.788,0.643$ and 0.958 , respectively. Thus, the developed method was robust and not affected by deliberate changes in the parameters of the proposed method.

The proposed DPV method is more sensitive than potentiometric method $\left(1.0 \times 10^{-6}-1.0 \times 10^{-2} \mathrm{~mol} / \mathrm{L}\right){ }^{7}$ spectrophotometric methods: $\left(6.038 \times 10^{-6}-7.25 \times 10^{-5}\right.$ $\mathrm{mol} / \mathrm{L}){ }^{10}\left(12.08 \times 10^{-6}-7.25 \times 10^{-5} \mathrm{~mol} / \mathrm{L}\right),{ }^{12}(2.41 \times$ $\left.10^{-5}-1.57 \times 10^{-4} \mathrm{~mol} / \mathrm{L}\right),{ }^{14}\left(6.03 \times 10^{-6}-6.03 \times 10^{-5}\right.$ $\mathrm{mol} / \mathrm{L}){ }^{16}\left(4.83 \times 10^{-5}-1.08 \times 10^{-4} \mathrm{~mol} / \mathrm{L}\right)^{17}$ and $(9.99 \times$ $\left.10^{-6}-4.40 \times 10^{-4} \mathrm{~mol} / \mathrm{L}\right),{ }^{19}$ conductometric method $(1.7 \times$

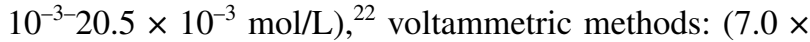
$\left.10^{-4}-6.0 \times 10^{-3} \mathrm{~mol} / \mathrm{L}\right){ }^{23}\left(4.0 \times 10^{-6}-6.3 \times 10^{-5} \mathrm{~mol} / \mathrm{L}\right)^{25}$ and $\left(9.0 \times 10^{-7}-5.0 \times 10^{-5} \mathrm{~mol} / \mathrm{L}\right)^{28}$ and chromatographic methods: $\left(9.057 \times 10^{-5}-2.71 \times 10^{-4} \mathrm{~mol} / \mathrm{L}\right),{ }^{31}(15.09 \times$ $\left.10^{-5}-48.29 \times 10^{-4} \mathrm{~mol} / \mathrm{L}\right)^{36}$ and $\left(15.09 \times 10^{-6}-12.08 \times 10^{-5}\right.$ $\mathrm{mol} / \mathrm{L})^{38}$

\section{7. Determination of MET in Cidophage Tablets}

The proposed voltammetric method was successfully applied to determine MET in its dosage form (Cidophage tablets) in the same linear range of the pure drug with mean recovery of $99.93 \%$ and mean relative standard deviation of $1.61 \%$ indicating that there was no interference from some common excipients used in pharmaceutical preparations. The results obtained were compared with those of the official potentiometric titration method with mean recovery of $99.78 \%$ and mean relative standard deviation of $1.97 \% .{ }^{47}$ Student's t-test (for accuracy) and the variance ratio F-test (for precision) in Table 1 showed that $\mathrm{t}$ and $\mathrm{F}$ values were smaller than the critical values, thus there was no any significant differences between the proposed voltammetric method and the official method with respect to accuracy and precision.

Table 1: Determination of MET in Cidophage tablets compared with the official method. ${ }^{47}$

\begin{tabular}{lcc}
\hline $\begin{array}{l}\text { Claimed } \\
(\mathbf{m g} / \text { tab })\end{array}$ & $\begin{array}{c}\text { Official method } \boldsymbol{m}^{47} \\
\text { Recovery }(\boldsymbol{\%}) \pm \mathbf{R S D}(\boldsymbol{\%}),(\mathbf{n}=\mathbf{5})\end{array}$ & $\begin{array}{c}\text { DPV method } \\
\text { Recovery }(\boldsymbol{\%}) \pm \mathbf{R S D}(\boldsymbol{\%}),(\mathbf{n}=\mathbf{5})\end{array}$ \\
\hline & $99.15 \pm 1.82$ & $100.75 \pm 1.45$ \\
500 & F-test & 1.95 \\
& t-test & 0.88 \\
\hline
\end{tabular}

Tabulated $\mathrm{F}$ and $\mathrm{t}$ values at $95 \%$ confidence level $=6.39$ and 2.776 , respectively ${ }^{46}$ 
The used DPV method is more sensitive than capillary electrophoresis method $\left(12.08 \times 10^{-4}-12.08 \times 10^{-3}\right.$ $\mathrm{mol} / \mathrm{L}){ }^{4}$ potentiometric methods: $\left(1.0 \times 10^{-6}-1.0 \times 10^{-1}\right.$ $\mathrm{mol} / \mathrm{L})^{8}$ and $\left(1.0 \times 10^{-5}-1.0 \times 10^{-1} \mathrm{~mol} / \mathrm{L}\right),{ }^{9}$ spectrofluorimetric method $\left(12.08 \times 10^{-5}-6.03 \times 10^{-3} \mathrm{~mol} / \mathrm{L}\right),{ }^{9}$ spectrophotometric methods: $\left(12.08 \times 10^{-5}-6.03 \times 10^{-3} \mathrm{~mol} / \mathrm{L}\right),{ }^{9}$ $\left(12.08 \times 10^{-6}-7.25 \times 10^{-5} \mathrm{~mol} / \mathrm{L}\right),{ }^{11}\left(6.03 \times 10^{-6}-9.66 \times\right.$ $\left.10^{-5} \mathrm{~mol} / \mathrm{L}\right)^{15}$ and $\left(12.08 \times 10^{-6}-6.03 \times 10^{-5} \mathrm{~mol} / \mathrm{L}\right)^{18}$ and chromatographic method $\left(15.09 \times 10^{-6}-12.08 \times 10^{-5}\right.$ $\mathrm{mol} / \mathrm{L})^{32}$

\section{8. Determination of MET in Spiked Urine}

The applicability of the proposed DPV method for the determination of MET in spiked human urine was investigated. Figure 11 illustrated the differential pulse voltammograms for different concentrations of MET in urine samples. The linearity range was $1.6 \times$ $10^{-6}-5.6 \times 10^{-6} \mathrm{~mol} / \mathrm{L}$ with mean recovery of $100.73 \%$ and mean relative standard deviation of $1.84 \%$. The LOD and LOQ were $9.14 \times 10^{-8} \mathrm{~mol} / \mathrm{L}$ and $3.05 \times 10^{-7}$ $\mathrm{mol} / \mathrm{L}$, respectively.

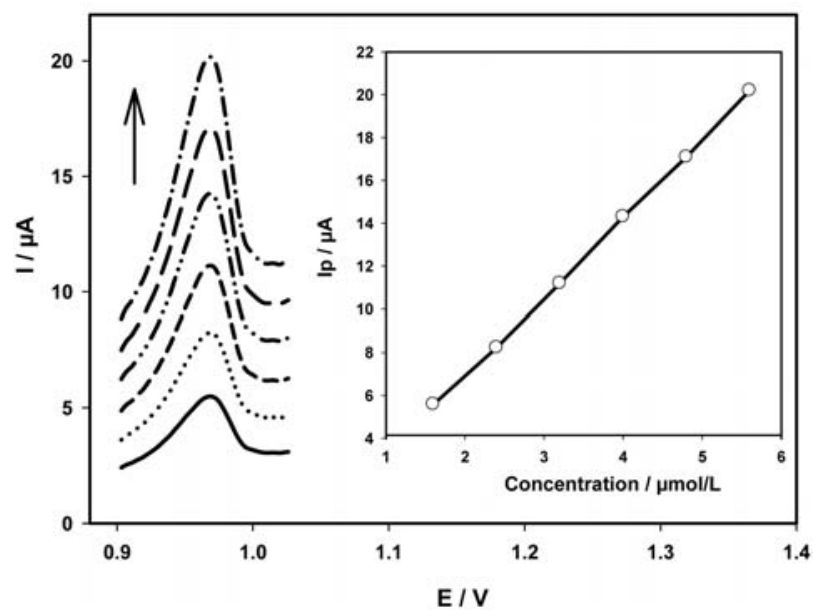

Figure 11: Differential pulse voltammograms for different concentrations of MET in urine samples at PYCPE in BR buffer ( $\mathrm{pH} 2.0)$, $\mathrm{T}_{\mathrm{acc}}=50 \mathrm{sec}$ and scan rate of $20 \mathrm{mV} / \mathrm{s}$. The inset: the relation between MET concentration and the current responses.

\section{Conclusion}

A simple electroanalytical voltammetric method was described for determination of MET in bulk drug, based on its electrochemical oxidation at pyrogallol modified carbon paste electrode. Under optimized conditions, the proposed method exhibited acceptable analytical performances in terms of linearity, accuracy and precision. To further validate its possible application, the method was used for the quantification of MET in tablets and urine.

\section{Acknowledgment}

The authors would like to express their gratitude to the National Organization for Drug Control and Research (NODCAR, Egypt) for providing instruments and the means necessary to accomplish this work.

\section{References}

1. A. J. Krentz, C. J. Bailey, Drugs, 2005, 65, 385-411. http://dx.doi.org/10.2165/00003495-200565030-00005

2. C. J. Bailey, R. C. Turner, New Engl. J. Med., 1996, 334, 574-579.

http://dx.doi.org/10.1056/NEJM199602293340906

3. R. A. DeFronzo, N. Barzilai, D. C. Simonson, J. Clin. Endocrinol. Metab., 1991, 73, 1294-1301.

http://dx.doi.org/10.1210/jcem-73-6-1294

4. I. I. Hamdan, A. K. B. Jaber, A. M. Abushoffa, J. Pharm. Biom. Anal., 2010, 53, 1254-1257. http://dx.doi.org/10.1016/j.jpba.2010.03.017

5. J. Z. Song, H. F. Chen, S. J. Tian, Z. P. Sun, J. Chromatogr. B., 1998, 708, 277-283. http://dx.doi.org/10.1016/S0378-4347(97)00635-X

6. H. H. Gadape, K. S. Parikh, E-J. Chem., 2011, 8, 767-781.

7. E. Khaled, M. S. Kamel, Sen. Electroanal., 2011, 6, 323- 335.

8. E. Khaled, M. S. Kamel, H. N. Hassan, Sh. Abd El-Alim, H. Y. Aboul-Enein, Analyst, 2012, 137, 5680-5687. http://dx.doi.org/10.1039/c2an35696a

9. S. S. M. Hassan, W. H. Mahmoud, M. A. F. Elmosallamy, A. M. Othman, Anal. Chim. Acta, 1999, 378, 299-311. http://dx.doi.org/10.1016/S0003-2670(98)00500-5

10. M. F. Abdel-Ghany, O. Abdel-Aziz, M. F. Ayad, M. M. Tadros, Spectrochim. Acta, 2014, 2014, 175-182.

11. S. M. Riad, M. R. Rezk, G. Y. Mahmoud, A. E. AbdelAleem, Int. J. Comprehe. Pharm., 2012, 3, 1-4.

12. R. I. El-Bagary, E. F. Elkady, B. M. Ayoub, Int. J. Biomed. Sci., 2011, 7, 62-69.

13. M. R. Sohrabi, N. Kamali, M. Khakpour, Anal. Sci., 2011, 27, 1037-1041. http://dx.doi.org/10.2116/analsci.27.1037

14. G. Mubeen, K. Noor, M. N. Vimala, Int. J. Chem. Tech. Res., 2010, 2, 1186-1187.

15. P. Saxena, A. S. Raghuwanshi, U. K. Jain, A. Patel, N. Gupta, Orient. J. Chem., 2010, 26, 1553-1556.

16. M. S. Arayne, N. Sultana, M. H. Zuberi, F. A. Siddiqui, $I n-$ dian J. Pharm. Sci., 2009, 71, 331-335. http://dx.doi.org/10.4103/0250-474X.56022

17. G. Mubeen, K. Noor, Indian J. Pharm. Sci., 2009, 71, 100102. http://dx.doi.org/10.4103/0250-474X.51947

18. P. S. Sudarshan, C. G. Bonde, Int. J. Chem. Tech. Res., 2009, 1, 905-909.

19. S. Ashour, R. Kabbani, Anal. Lett., 2003, 36, 361-370. http://dx.doi.org/10.1081/AL-120017696

20. M. G. El-bardicy, S. Z. El-khateeb, A. S. Ahmad, H. N. Assaad, Spect. Lett., 1989, 22, 1173-1181. http://dx.doi.org/10.1080/00387018908054014 
21. E. R. Sartori, W. T. Suarez, O. F. Filho, Quim. Nova, 2009, 32, 1947-1950. http://dx.doi.org/10.1590/S0100-40422009000700043

22. J. M. Calatayud, P. C. Falco, M. C. P. Marti, Anal. Lett., 1985, 18, 1381-1390. http://dx.doi.org/10.1080/00032718508066218

23. L. M. B. Jerez, U. M. G. Perez, P. Z. Robledo, J. H. Moreira, Int. J. Electrochem. Sci., 2014, 9, 4643- 4652

24. M. B. Gholivand, L. M. Behzad, Anal. Biochem., 2013, 438, 53-60. http://dx.doi.org/10.1016/j.ab.2013.03.019

25. N. Sattarahmady, H. Heli, F. Faramarzi,. Talanta, 2010, 82, 1126-1135. http://dx.doi.org/10.1016/j.talanta.2010.06.022

26. X. J. Tian, J. F. Song, J. Pharm. Biomed. Anal., 2007, 44, 1192-1196. http://dx.doi.org/10.1016/j.jpba.2007.04.014

27. S. Skrzypek, V. Mirceski, W. Ciesielski, A. Soko ${ }^{3}$ owski, R. Zakrzewski, J. Pharm. Biomed. Anal., 2007, 45, 275-281. http://dx.doi.org/10.1016/j.jpba.2007.07.010

28. X. J. Tian, J. F. Song, X. J. Luan, Y. Wang, Q. Shi, Anal. Bioanal. Chem., 2006, 386, 2081-2086. http://dx.doi.org/10.1007/s00216-006-0869-4

29. L. Yongming, L. Guizhi, J. Anal. Chem., 2001, 29, 20012009.

30. I. H. I. Habib, M. S. Kamel, Talanta, 2003, 60, 185-190. http://dx.doi.org/10.1016/S0039-9140(03)00123-1

31. S. K. Konidala, P. Hemanth, Int. J. Curr. Pharm. Res., 2014, 6, 31-35.

32. H. P. Chhetri, P. Thapa, A. V. Schepdael, Int. J. Pharm. Sci., Res. 2013, 4, 2600-2604.

33. S. R. Polagani, N. R. Pilli, R. Gajula, V. Gandu, J. Pharm. Anal., 2013, 3, 9-19. http://dx.doi.org/10.1016/j.jpha.2012.09.002

34. R. I. El-Bagary, E. F. Elkady, B. M. Ayoub, Talanta, 2011, 85, 673-680. http://dx.doi.org/10.1016/j.talanta.2011.04.051
35. C. Georgita, I. Sora, F. L. Albu, C. M. Monciu, Farmacia, 2010, 58, 158-169.

36. F. Al-Rimawi, Talanta, 2009, 79, 1368-1371. http://dx.doi.org/10.1016/j.talanta.2009.06.004

37. Y. Wang, Y. Tang, J. Gu, J. P. Fawcett, X. Bai, J. Chromatogr. B., 2004, 808, 215-219. http://dx.doi.org/10.1016/j.jchromb.2004.05.006

38. A. Zarghi, S. M. Foroutan, A. Shafaati, A. Khoddam, J. Pharm. Biomed. Anal., 2003, 31, 197-200. http://dx.doi.org/10.1016/S0731-7085(02)00608-8

39. C. L. Cheng, C. H. Chou, J. Chromatogr. B., 2001, 762, 5158. http://dx.doi.org/10.1016/S0378-4347(01)00342-5

40. H. M. Ahmed, M. A. Mohamed, W. M. Salem, Anal. Methods, 2015, 7, 581-589. http://dx.doi.org/10.1039/C4AY02450H

41. D. L. Vu, B. Ertek, Y. Dilgin, L. Cervenka, Quim. Nova, 2014, 37, 1629-1232.

42. V. Moncada, A. A. Lueje, J. Chil. Chem. Soc., 2014, 59, 2516-2519. http://dx.doi.org/10.4067/S0717-97072014000200026

43. P. S. Feng, S. M. Wang, W. Y. Su, S. H. Cheng, J. Chin. Chem. Soc., 2011, 59, 1-8.

44. N. C. T. Martins, M. F. C. Guedes Da Silva, J. A. L. Da Silva, J. J. R. Frausto Da Silva, C. Paliteiro, A. J. L. Pombeir, Portugaliae Electrochim. Acta, 2001, 19, 367-370. http://dx.doi.org/10.4152/pea.200103367

45. D. K. Gosser: Cyclic Voltammetry Simulation and Analysis of Reaction Mechanism, NewYork, USA: VCH, 1993, p. 43.

46. J. C. Miller, J. N. Miller: Statistics for Analytical Chemistry. NewYork, USA, Ellis Horwood Series, 1993, pp. 115-117.

47. United States Pharmacopoeia and National Formulary (USP 30-NF25). Rockville, 2007, pp. 2595-2596.

\section{Povzetek}

S ciklovoltametrijo in diferencialno pulzno voltametrijo smo raziskovali elektrooksidativno obnašanje in določanje antihiperglikemika metforminijevega hidroklorida, za kar smo uporabili s pirogalolom modificirano elektrodo iz ogljikove paste. Ugotovili smo, da gre v širokem intervalu pH (Britton Robinsonov pufer, $\mathrm{pH}$ 2-9) za ireverzibilno oksidacijo analita. Zveza med merjenim maksimalnim tokom in koncentracijo analita je linearna $\mathrm{v}$ območju koncentracij med 8,0 $\times 10^{-7}$ in $6,0 \times 10^{-6} \mathrm{~mol} / \mathrm{L}$, meja zaznave je $6,63 \times 10^{-8} \mathrm{~mol} / \mathrm{L}$, meja določitve pa $2,21 \times 10^{-7} \mathrm{~mol} / \mathrm{L}$. Metoda je bila uporabljena za določitev metforminijevega hidroklorida $\mathrm{v}$ farmacevtskih oblikah in $\mathrm{v}$ urinu. 